\title{
Spatial Pattern Analysis on Dengue Hemorrhagic Fever (DHF) Disease in Tanjung Emas Port Area using Moran Index
}

\author{
Mukhammad Pujianto ${ }^{1}$, Mursid Raharjo ${ }^{2}$, Nurjazuli ${ }^{3}$
}

\author{
${ }^{1}$ Magister of Environmental Health, Faculty of Public Health, Diponegoro University, Indonesia \\ ${ }^{2,3}$ Lecture in Faculty of Public Health, Diponegoro University, Indonesia
}

\begin{abstract}
Tanjung Emas Port area is the State's entrance in Semarang City's administrative area. Data shows a significant increase of Dengue Hemorrhagic Fever (DHF) disease cases from 38 cases in 2018 to 137 cases in 2019. The objective of research was to conduct a spatial analysis using spatial autocorrelation to find out the correlation pattern between locations. A descriptive and analytical observational study of 137 coordinate points of DHF patients was carried out for mapping purpose. This research employed spatial autocorrelation with Moran's Index. Using such the method, the spatial autocorrelation of DHF spread can be determined, and so can be the spatial distribution of DHFin Tanjung Emas Port area, Semarang. Spatial autocorrelation analysis showed Moran's Index value of 0.192725 at interval of $0<I \leq 1$ indicating positive spatial autocorrelation; Moran's index $>0$ indicates the Cluster spread pattern. One-way significance test showed the positive autocorrelation in Dengue hemorrhagic fever case in Tanjung Emas Port and cluster spread spatial pattern.
\end{abstract}

Keywords-Dengue Hemorrhagic Fever, Spatial Autocorrelation, Moran's Index.

\section{INTRODUCTION}

Dengue hemorrhagic fever (DHF) case is still fairly high in Indonesia, about 65,602 cases in 2018, with Incidence Rate (IR) of 24.73 per 100,000 Population and Case Fatality Rate (CFR) of $0.70 \% .^{1)}$ In Central Java province area, DHF disease is still a serious problem, as 35 regencies/cities have ever been affected by this disease, with 3,133 DHF cases. ${ }^{2)}$ Semarang City is an endemic region in Central Java Province. Data of Semarang City's Health Office shows that an extraordinary incidence has occurred on December 2018 at City level, with 27 cases. In 2018 there were 102 DHF cases (IR $=6.17)$ and 1 death $\left.(\mathrm{CFR}=0.97 \%) .{ }^{3}\right)$ Tanjung Emas Port belongs to Semarang City's administrative area as the state's entrance and national and international ship traffic. Tanjung Emas Port area consists of 2 subareas: perimeter and buffer. Buffer subarea belongs toPort Health Office (KKP) Class II of Semarang work area located in a land with 2 (two)kilometers radius beyond the Perimeter subarea. ${ }^{4)}$

Dengue Hemorrhagic Fever (DHF) is a disease found widely in some tropical and subtropical regions, particularly South East Asian, Central American, American and Caribbean areas. The natural host of DHF is human being, while its agent is dengue virus belonging to
Flaviridae family and Flavivirus genus, consisting of 4 serotypes: Den-1, Den-2, Den-3 and Den-4. DHF is transmitted to human beings through the bite of mosquito infected, particularly Aedesaegypti and Ae. Albopictus mosquito. ${ }^{5)}$

The control of DHF in Tanjung Emas Port area including perimeter and buffer subareas is inseparable from the activity of controlling environmental risk conducted by Port Health Office (KKP) Class II of Semarang. The objective of research is to find out whether or not there is a spatial autocorrelation and the spread pattern of dengue hemorrhagic fever (DHF) in Tanjung Emas Port area, so that the spatial information provided can be utilized as surveillance data understandable to DHF program holders. This research is expected to be basic information for program planning and decision making to policy holder in the attempt of preventing and controlling DHF cases.

Some spatial analytical studies on DHF disease have been conducted, one of which is Andri Ruliansyah's study on Spatial Analysis of Dengue Hemorrhagic Fever in Tasikmalaya city, in 2011-2015. 


\section{METHODS}

Data of DHF case came from Semarang City's Health Office in 2019. The sample of research was total population of DHF patients in Tanjung Emas Port area, based on hospital's diagnosis. Data collection was conducted by plotting DHF patients' houses using GlobalPositioning System (GPS). The result of plotting is included into Semarang City's Basic Map on which Buffering has been conducted over 2-km Port land. The combining process aims to represent qualitative and quantitative data visually with 2-kilometer radius. Thus, spatial data of Dengue Hemorrhagic Fever disease was obtained. The spatial data provides integrated information, the location of Tanjung Emas Port area in the form of vector and attribute information constituting the number of Dengue Hemorrhagic Fever casesin each of locations. Furthermore, the calculation process was conducted using spatial statistical model to identify the autocorrelation occurring, whether it is positive or negative. Spatial data analysis was conducted using ArcGIS.GIS was used to solve problem and to give necessary understanding in using its analytical system and result. ${ }^{6)}$

The author employed a map developing application for data processing purpose. Shapefile(shp) produced was then opened on the map developing application to be processed further. The application will edit all Shapefile to produce sign or symbol that can represent individual characters. The spatial analysis used is the spatial autocorrelation of DHF disease spread measured using spatial autocorrelation using Moran's index. The interval of Moran's index value in standardized spatial weighted matrix case is $-1 \leq \mathrm{I} \leq 1$. Value interval of $-1 \leq \mathrm{I}<0$ indicatesnegative spatial autocorrelation while value interval of $0<\mathrm{I} \leq 1$ indicates positive spatial autocorrelation, Moran's index value of zero (0) indicates spreading. Moran's Index value of I (I) found by calculating the spatial autocorrelation can indicate the created feature pattern. ${ }^{7)}$

Table 1. Created Feature Pattern

\begin{tabular}{ll}
\hline Moran's I & Notes \\
\hline I $>0$ & $\begin{array}{l}\text { Cluster (there are many value similarities in } \\
\text { the feature ) }\end{array}$ \\
$\mathrm{I}<0$ & Random (unclear feature pattern) \\
$\mathrm{I}=0$ & $\begin{array}{l}\text { Spreading (high and low feature values } \\
\text { spread in dataset) }\end{array}$
\end{tabular}

Source: (Mitchell, 2005)

This research has passed successfully the ethical study conducted by Ethical Commission of Health Researchers, Faculty of Public Health, Diponegoro University, No: 540/EA/KEPK-FKM/2019, on November 27, 2019.

\section{RESULTS}

Tanjung Emas Port, in addition to serving as an economic and trading center, is also the entrance and the exit of transportation vehicles, people, and commodities at national and international scales in Central Java Province. Data of 2019 shows 381 ships from foreign countries and 11,988 ships home visiting this port. ${ }^{8}$ Therefore, an attempt should be taken to detect, to prevent, and to respond to any diseases potentially resulting in public health emergency, including DHF disease, in Tanjung Emas Port area.

Table 2. Distribution of DHF in 2019 of Urban Village inTanjung Emas Port Area.

\begin{tabular}{llcllc}
\hline No & Village & DHF Case & No & Village & DHF Case \\
\hline 1 & Bandarharjo & 7 & 16 & MuktiharjoLor & 0 \\
2 & Bangun Harjo & 0 & 17 & Pandansari & 1 \\
3 & Bugangan & 0 & 18 & PanggungKidul & 4 \\
4 & BuluLor & 1 & 19 & PanggungLor & 16 \\
5 & Dadapsari & 7 & 20 & Plombokan & 1 \\
6 & Kaligawe & 2 & 21 & Purwodinatan & 4 \\
7 & Kauman & 0 & 22 & Purwosari (North Semarang) & 6 \\
8 & Kebonagung & 1 & 23 & Rejomulyo & 2 \\
9 & Kembangsari & 0 & 24 & SawahBesar & 0 \\
10 & Kemijen & 15 & 25 & Sekayu & 0 \\
11 & Kranggan & 0 & 26 & Tambakrejo & 4
\end{tabular}


International Journal of English, Literature and Social Sciences, 5(2)

Available online: https://ijels.com/

\begin{tabular}{llcccc}
12 & Kuningan & 16 & 27 & Tanjungmas & 28 \\
13 & Mlatibaru & 10 & 28 & Tawang Mas & 0 \\
14 & Mlatiharjo & 11 & 29 & Tawang Sari & 1 \\
15 & MuktiharjoKidul & 0 & 30 & TerboyoKulon & 0 \\
& & 31 & TerboyoWetan & 0 \\
\hline
\end{tabular}

The data shown in the table above shows the list of 31 in2-kilometer buffer of Tanjung Emas Port land. villages and the spread of DHF case (137 cases)

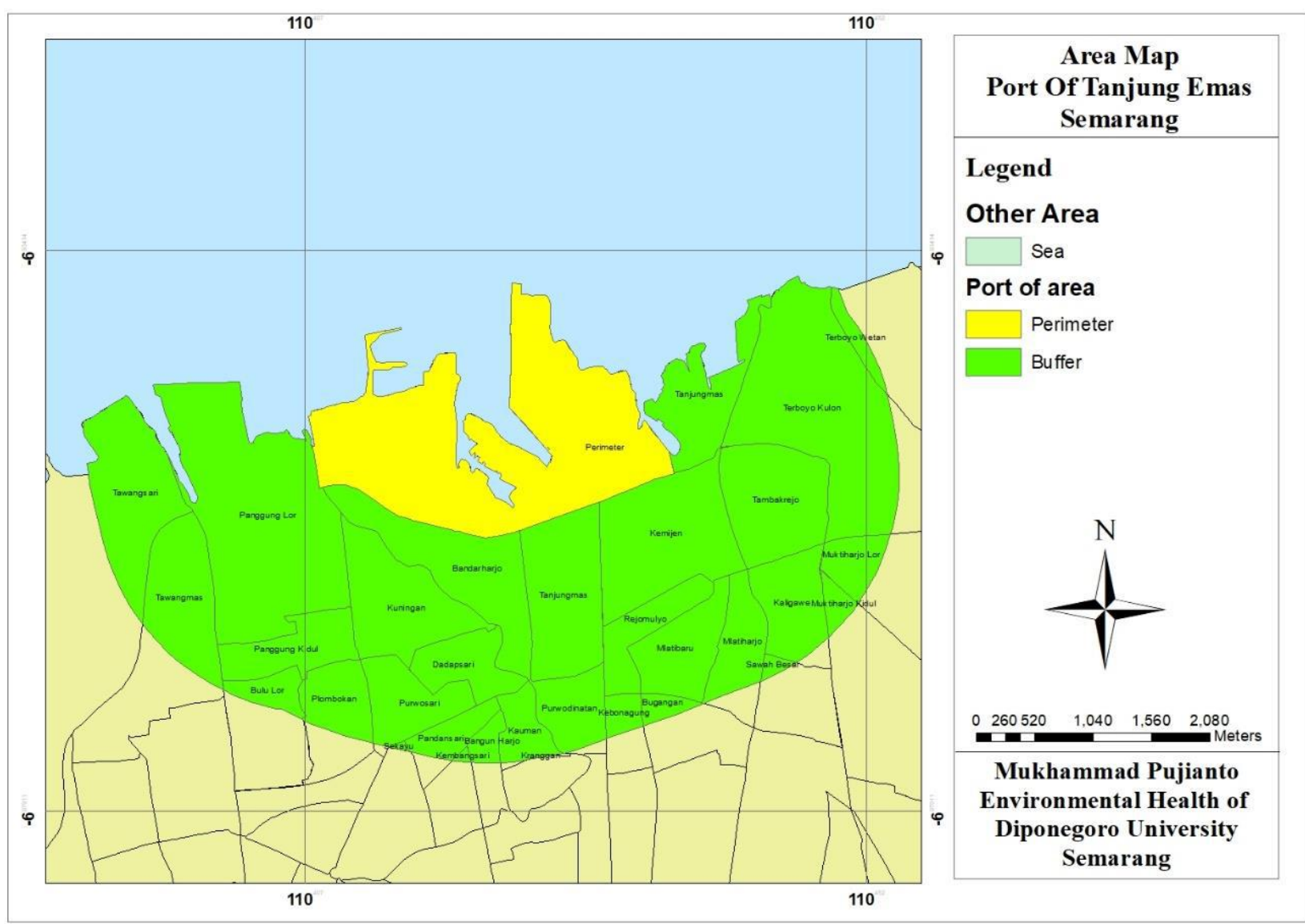

Fig.1: Map of Perimeter and Buffer Subareas in Tanjung Emas Port. 


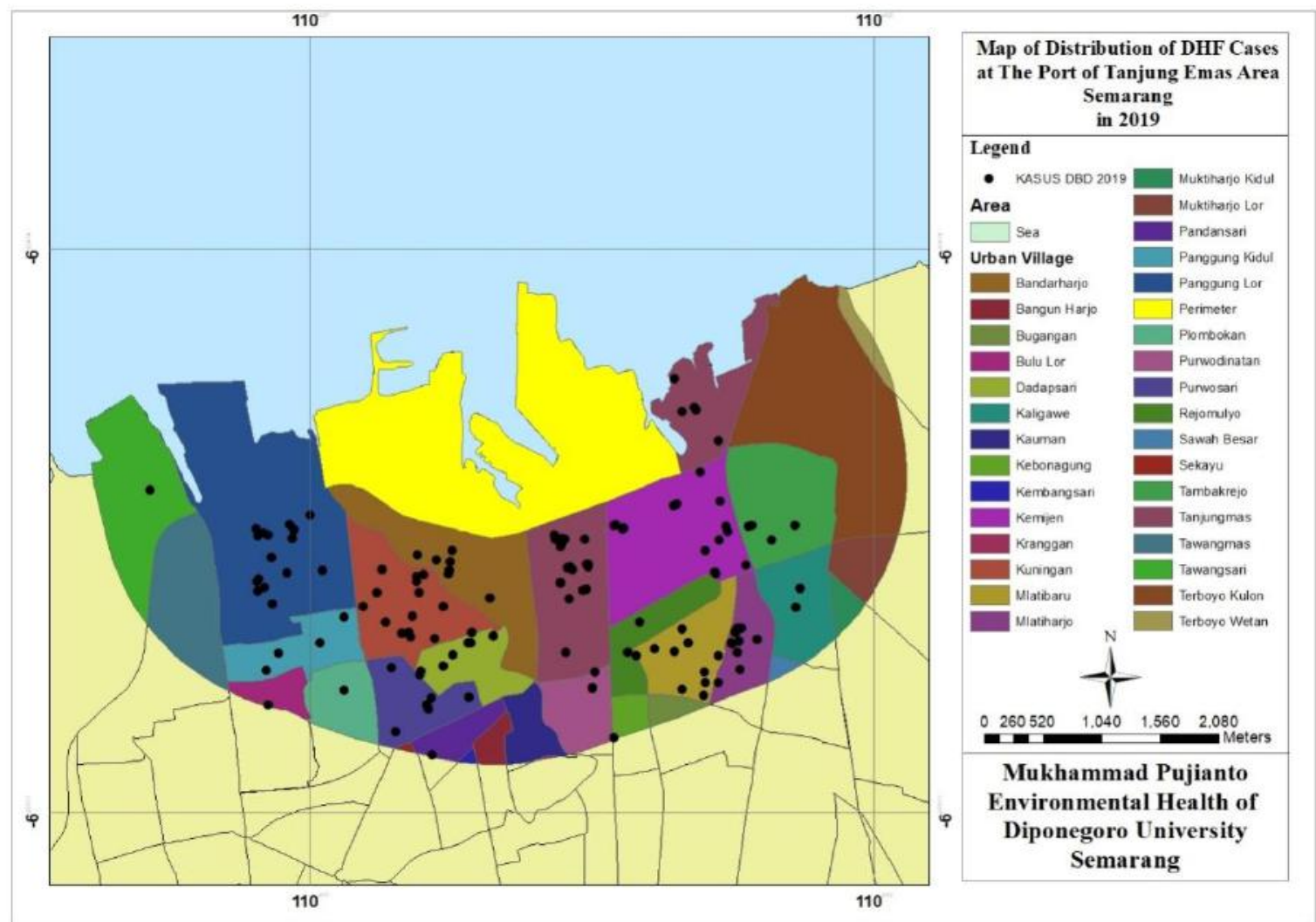

Fig.2: Distribution of DHF patients in Tanjung Emas Port area, Semarang, in 2019

Figure 1reveals the Map of Tanjung Emas Port area consisting of Perimeter and Buffer subareas. Buffer subarea includes $2-\mathrm{km}$ land beyond Kilometer area, with administrative area distributed in 31 urban villages in Semarang City.

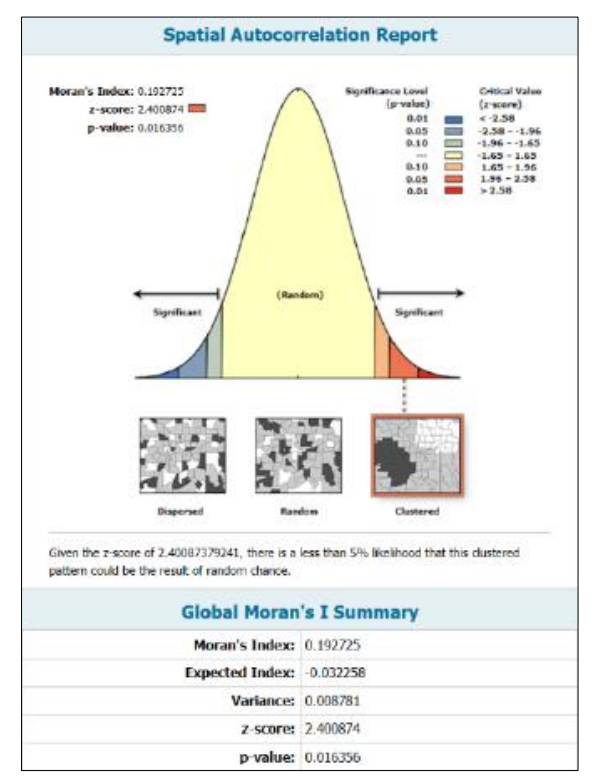

Fig.3: Result of Spatial Autocorrelation Analysis on

Dengue Hemorrhagic Fever Disease in 2019
The map above shows that there are 12 Villages free of DHF case, while 29 Villages are the area with DHF cases, with Tanjung EmasUrban Village being the areas with highest number of DHF cases, 28 cases.

From the result of spatial autocorrelation analysis on Dengue Hemorrhagic Fever as shown in Figure 4, it can be obtained Moran's Index value of 0.192725 at value interval of $0<\mathrm{I} \leq 1$ indicating the positive spatial autocorrelation, Moran's Index value $>0$ indicating Cluster spread pattern (there are many value similarities in the feature). Recalling $\mathrm{Z}$-score of 2,400874 , there is a less than $5 \%$ probability that this cluster pattern can be random result, thereby having confidence interval of $95 \%$.

\section{DISCUSSION}

In this research, DHF case was obtained based on hospital's diagnosis as reported by Semarang City's Health Office. Spatial interrelationship in DHF spread is measured using spatial autocorrelation with Moran's Index, indicating the positive spatial autocorrelation in 2019. The cluster case spread pattern indicates that there is vector habitat concentration, thereby more potentially resulting in local transmission. It is in line with another study finding 
that DHF spread shows positive spatial autocorrelation, with cluster case spread pattern (in group or colony); the areas where clusters are formed are the ones vulnerable to DHF disease. ${ }^{9)}$

Still another study found that there is a significant relationship between DHF incidence and Larva Free Index (LFI), House Index (HI), Container Index (CI), and behavior. The highest risk of DHF transmission occurs in the location with unqualified LFI, HI, CI, and DHF preventing behavior. Spatial analysis revealed that risky LFI and HI, and poor practice of coping with mosquito nest increase the DHF incidence rate. ${ }^{10)}$

Generally, the clustering of DHF incidence tends to follow the high population density and the low larva-free index (LFI). It is in line with Agcrista Permata Kusuma's study finding that the cluster pattern of DHF spread occurs in the urban villages with highest population density potentially leading to DHF transmission. ${ }^{11)}$ This current study is also in line with the research conducted by Rika Hernawati on Spatial Pattern Analysis of Dengue Hemorrhagic Fever in Bandung City using Moran's Index finding that there is a positive spatial autocorrelation. From the result of significance test with Moran's index method, it can be concluded that the spatial spread pattern created for Dengue Hemorrhagic Fever has cluster spread pattern. ${ }^{12)}$ The cluster spread pattern also occurs in Tanjung Pinang city and the result of analysis indicates that there is a relationship of $\mathrm{H} 1$ and RR to DHF spread pattern in Tanjung Pinang. ${ }^{13)}$

The risk factor of environment is also closely related to the cluster spatial pattern occurring. The significant relationship also occurs in the area with high rainfall with high DHF case, while the area with high larva free index (LFI) is closely related to low DHF case, the area with high population density is related to high DHF case incidence, so that the preventive attempt can be taken by increasing LFI in each area and increasing the alertness in the areas with high population density and rainfall. ${ }^{14)}$

Integrated Vector Management (IVM)is one of attempts taken to control DHF case. Similarly, Mursid Raharjo's study on malaria control in Purworejo found that no ecological monitoring for early warning system, poor collaboration between sectors, no cross-institutional program, and no society's culture in managing malaria are main factors leading to the ineffectiveness of IVM and the increased number of vector-transmitted disease case. ${ }^{15)}$ In addition to IVM, the reengineering of vector control is very desirable. Nanotechnology is the new form of reengineering in vector control and it has been developed. Toxicity test on nano-particle (Ag2NO3) shows that
nanosilver(Ag2NO3) kills the tested animal (Aedesaegypti larva) more effectively. ${ }^{16)}$

Population density factor affects transmission process or the process by which a disease moves from an individual to another. Without adequate preventive attempt, the denser the population, the more conducive is the situation to the proliferation of virus, thereby resulting in the increase in the case number. Population density needs special attention from government, in relation to human's life feasibility particularly due to unplanned and uncontrolled urbanization. For that reason, information on population distribution geographically is required to enable the government to solve the population density problem. Information on density highly affects the health interest efforts. ${ }^{17)}$

Climate change contributes considerably to the increase and the emergence of vector with new species. It is in line with a previous study finding that weather triggers the increase of Anopheles species population. Anopheles aitkenii is identified as a new species with density of 4 species/day and is the vector of malaria transmission. ${ }^{18)}$

Environment and behavior factor also contributes considerably to the increased number of vector-transmitted disease cases. A study conducted in Pekalongan found that environment and behavior factor contributes to filariasis case incidence. ${ }^{19)}$ Meanwhile a study conducted in Semarang Regency revealed that water reservoir containing larva and habit of applying mosquito repellent are related significantly to DHF incidence. ${ }^{20)}$ The presence of place where mosquito proliferates, the number of mosquito proliferation places, $\mathrm{ABJ}, \mathrm{CI}$, and $\mathrm{HI}$ are related to DHF case. ${ }^{21)}$

Surveillance should be conducted on endemic area of DHF and other vector borne diseases for the controlling program purpose. It is in line with a studied conducted in Pekalongan City finding Culexquinquefasciatus, Aedesaegypti, and Armigeressubalbatus mosquito. The surveillance activity is intended to be an effective attempt of controlling filariasis and DHF in the future. ${ }^{22)} \mathrm{Bad}$ habitat appropriate to mosquito's proliferation place and public participation can contribute considerably to the transmission of Filariasis and other vector borne diseases. $^{23)}$

\section{CONCLUSION}

The spread of Dengue Hemorrhagic Fever cases in Tanjung Emas Port area occurs in cluster, so that the surrounding areas are vulnerable to DHF disease. Spatial 
analysis is recommended to be done more in DHF case endemic area periodically as it can provide basic information in the attempt of preventing and controlling DHF case.

\section{ACKNOWLEDGMENTS}

The authors would like to expresses our gratitude to Health Human Resource Development and Empowerment Agency, the Ministry of Health of the Republic of Indonesia for funding this research. The authors would also like to acknowledge the Port Health Office (KKP) Class II of Semarang, Semarang City Health Office, for contribution and support during the research.

\section{REFERENCES}

[1] Pusat Data dan Informasi. (2019). Data dan Informasi Profil Kesehatan Indonesia tahun 2018. Jakarta.

[2] Dinas Kesehatan Provinsi Jawa Tengah. (2019). Profil Kesehatan Provinsi Jawa Tengah tahun 2018. pp. 2-6.

[3] Dinas Kesehatan Kota Semarang. (2018). Profil Kesehatan Kota Semarang 2018. Dinkes Semarang GoId. pp.1-104.

[4] Kemenkes RI.(2008). Permenkes RI No. 356 Tahun 2008 Tentang Organisasi dan Tata Kerja Kantor Kesehatan Pelabuhan. pp.1-14.

[5] Candra A. (2009). Aspirator Jurnal Penelitian Penyakit Tular Vektor = Journal of Vector-borne Diseases Studies. ASPIRATOR - J Vector-borne Dis Stud [Internet]. 2(2):110 $9 . \quad$ Retrieved from: http://ejournal2.litbang.kemkes.go.id:81/index.php/aspirator/a rticle/view/1787

[6] Brimicombe A. (2013). GIS, Environmental modeling and Engineering. Journal of Chemical Information and Modeling. 53, 1689-1699.

[7] Mitchell A. (2005). The ESRI Guide to GIS analysis. Spartial Measurements and Statistics.. ESRI press. (2), 240.

[8] Direktorat Surveilans dan Karantina Kesehatan, Penyakit DJP dan P, RI KK. (2019). Sistem Informasi Manajemen Kesehatan Pelabuhan. Retrieved from: https://sinkarkes.kemkes.go.id/

[9] Ruliansyah A, Yuliasih Y, Ridwan W, Kusnandar AJ. (2017). Analisis Spasial Sebaran Demam Berdarah Dengue di Kota Tasikmalaya Tahun 2011 - 2015. ASPIRATOR - J Vectorborne Dis Stud. 9(2), 85-90.

[10] Dwi Rivyantati R, Fitriana Arifin N, Rahardjo M, Hanani Darundiati Y. (2016). Application of Spatial Analysis Of Dengue Hemorrhagic Fever Risk Favtors In Taman District Madiun. J Kesehat Masy.15(2), 112-120. Retrieved from: http://publikasi.dinus.ac.id/index.php/visikes/article/viewFile/ 1441/1064

[11] Kusuma AP, Sukendra DM. (2016). Analisis Spasial Kejadian Demam Berdarah Dengue Berdasarkan Kepadatan Penduduk. Unnes J Public Heal.; 5(1), 48.

[12] Rika Kurniawati, Dwi Martiana Wati YA. (2015). Analisis
Spasial Sebaran Kasus Demam Berdarah Dengue (DBD) di Kabupaten Jember Tahun 2014 Spatial Analysis of Dengue Hemorrhagic Fever Distribution in Jember 2014. Artik Ilm Has. 1-7. Retrieved from: http://repository.unej.ac.id/bitstream/handle/123456789/6920 8/Rika Kurniawati.pdf?sequence=1.

[13] Ramdani K. (2019). Integrated Vector Management as an Effort to Anticipate the Spread of DHF in Tanjungpinang. Int J English Lit Soc Sci. 4(2):424-30.

[14]Rika Kurniawati, Dwi Martiana Wati YA. (2015). Analisis Spasial Sebaran Kasus Demam Berdarah Dengue (DBD) di Kabupaten Jember Tahun 2014 Spatial Analysis of Dengue Hemorrhagic Fever Distribution in Jember 2014. Artik Ilm Has. 1-7.

[15]Raharjo M, . Y. P. (2018). The Effectiveness of Integrated Vector Management (IVM) in Eliminating Malaria in Indonesia: A Case Study in the Purworejo District, Central Java Province, Indonesia. KnE Life Sci. 4(4), 1.

[16]Raharjo M, Subagyo A, Sulistyani. (2019). Nanoparticle of Silver Nitrate (Ag2NO3) and Carbamate (CO2NH3 derivatives) for Vector Control of Aedes aegypti. E3S Web Conf. 125(3), 2-6. Retrived from: https://www.e3sconferences.org/articles/e3sconf/pdf/2019/51/e3sconf_icenis2 019_16005.pdf

[17]Achmadi UF. (2012). Manajemen Penyakit Berbasis Wilayah. Revisi. Jakarta: Rajawali Press.

[18] Raharjo M, Darundiati Y, Praba G. (2018) The New Spesies Anopheles aitkeni as the Threat of Malaria in Indonesia. New Spesies Anopheles aitkeni as Threat Malar Indones [Internet]. 9(4), 206-10. Retrived from: https://www.indianjournals.com/ijor.aspx?target=ijor:ijphrd\& volume $=9 \&$ issue $=4 \&$ article $=040$

[19]Windiastuti IA, Suhartono, Nurjazuli. (2013). Hubungan Kondisi Lingkungan Rumah, Sosial Ekonomi, dan Perilaku Masyarakat Dengan Kejadian Filariasis di Kecamatan Pekalongan Selatan Kota Pekalongan. J Kesehat Lingkung Indones. 12(1), 51-7.

[20]Pramudiyo Teguh Sucipto, Mursid Raharjo N, (2015). ABSTRACT. Faktor - Faktor Yang Mempengaruhi Kejadian Penyakit Demam Berdarah Dengue (DBD) Dan Jenis Serotipe Virus Dengue Di Kabupaten Semarang. J Kesehat Lingkung Indones. 14(2).

[21] Yuanita YN, Setiani O, Wahyuningsih NE. (2019). Spatial Analysis of Breeding Place and Larva Density Existence with DHF (Dengue Hemorrhagic Fever) Incidence Rate in Pringsewu District, Indonesia. Int J English Lit Soc Sci. 4(5), 1357-64.

[22] Nurjazuli. (2015). Entomology Survey Based on Lymphatic Filariasis Locus in the District of Pekalongan City Indonesia. Int J Sci Basic Appl Res.22(1):295-302. Retrieved from: https://gssrr.org/index.php/JournalOfBasicAndApplied/articl e/view/3933/2279

[23] Nurjazuli N, Setiani O, Lubis R. (2018). Analysis of lymphatic filariasis transmission potential in Pekalongan city, central Java, Indonesia. Asian J Epidemiol. 11(1):20-5. Retrieved from: https://scialert.net/abstract/?doi=aje.2018.20.25 